\title{
A Financial Analysis of John Wood Group Plc
}

\author{
M. B. Suleiman \\ Federal Polytechnic, Mubi Nigeria
}

\author{
S. A. Opio \\ Office of the Auditor General of Uganda, Kampala \\ J. Ariko \\ Office of the Auditor General of Uganda, Kampala \\ E. Ssali \\ Office of the Auditor General of Uganda, Kampala
}

\begin{abstract}
This report focuses on the financial analysis of John Wood Group Plc. It was aimed at analysing the company's risk profile with regards to business risk, systematic risk, financial risk, and trend and comparative analysis. Furthermore, it also aimed at evaluating four approaches to company valuation, and the past and possible future agency problems in the company. The report used the company's annual accounts from 2010 to 2013 and for comparative purpose, two peers were considered. It was observed from the analysis that the business risk and systematic risks were high while the financial risk was low. On the company valuations, the Dividend Valuation Model (DVM) was selected among other models because the DVM computed value of the company was closest to the market value. More so, it was also observed based on the analysis that agency problems existed in the past and could possibly occur in the future. The report recommended that the company's business risk could be minimised by maintaining high operating leverage during boom and low operating leverage during recession. In doing this, it suggested the need for trade-off between financial leverage and operating leverage. Furthermore, the reported recommended various measures the company could mitigate and avert possible occurrence of agency problem.
\end{abstract}

\section{INTRODUCTION}

This report focused on John Wood Group Plc, an international energy service company with operations in more than 50 countries. The Group has three businesses- Wood Group Engineering, Wood Group PSN and Wood Group GTS - providing a range of engineering, production support, maintenance management and industrial gas turbine overhaul and repair services to the oil \& gas, and power generation industries worldwide (Wood Group's Annual Report and Accounts 2013). Amec Foster Wheeler Plc and WS Atkins Plc were considered as peers to Wood Group Plc (ft.com 2015). The report analysed the risk profile of Wood Group in comparison to its peers. It also considered the various approaches for company valuation, and then selected the model that gave the value closer to the market value. Furthermore, the report critically analysed the past and future agency problems in Wood Group and finally concluded.

\section{RISK PROFILE ANALYSIS}

This section covered risk profile analysis of Wood Group (WG) using accounting and marketbased risk measures (Appendix i). It covered analysis of business risk, systematic risk, financial risk, and a trend and comparative analysis of key ratios. 


\section{Business Risk Analysis}

Business risk shows degree of risk of company's operations. Business risk of a firm can be determined using degree of operating leverage. Wood Group's Degree of Operating Leverage (DOL) in 2012 and 2013 was 26.56 and 2.14 respectively. In comparison to its peers, Wood Group's DOL seems to be higher as shown in figure 1. Generally, a DOL above 1 is considered to be high implying that fixed costs may be higher than variable costs (Vernimmen et. al 2009). The high operating leverage could be due to volatility of revenue, costs of revenue and EBIT as shown in figure 2 . The volatility in cost of sales could be due to increase in depreciation and amortisation costs. These could be as a result of acquisitions such as PSN, Elkhom leading to increase in fixed assets. Furthermore, increase employee costs may be due to additional number of staff in the year 2012 and 2013 by 5,631 and 1,995 respectively (Annual Reports and Accounts 2012, 2013). However, during economic boom, a high operating leverage could be an opportunity for the company and at recession a threat.

Figure 1: Shows Degree of operating leverage

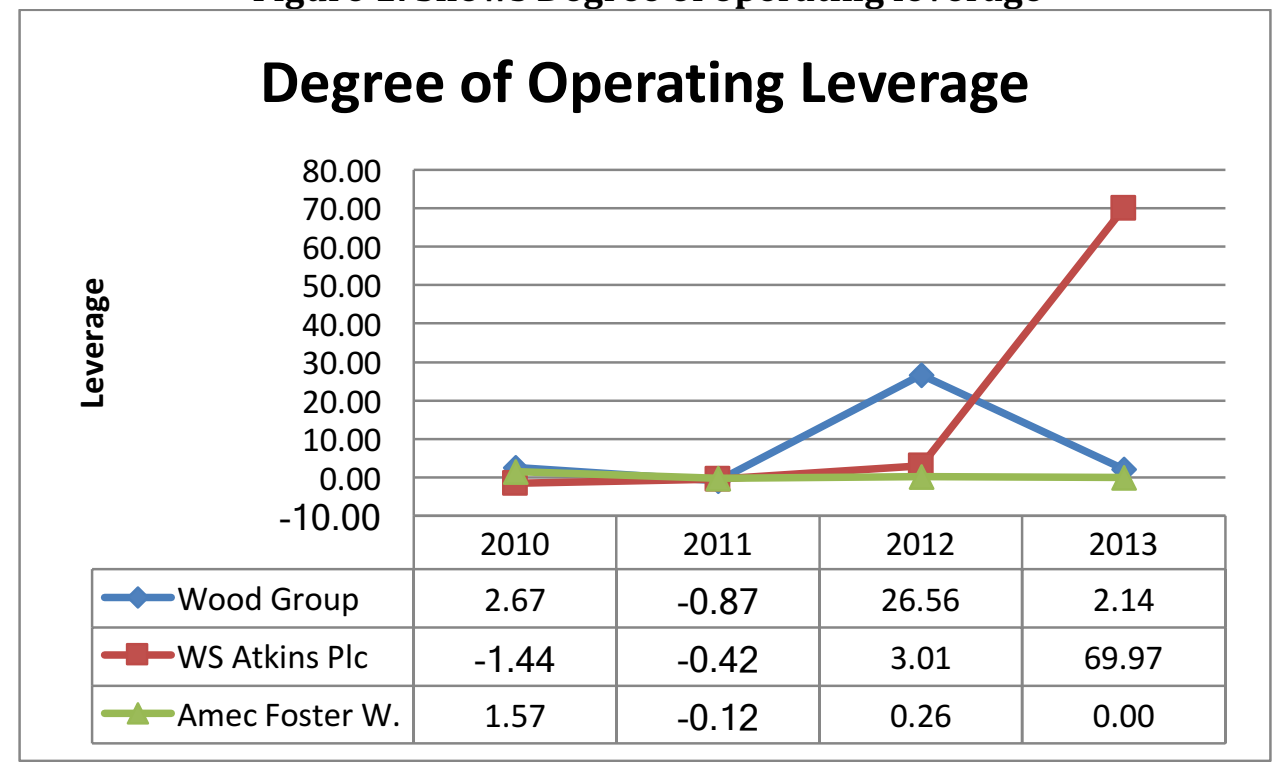

Source: Authors

Figure 2: Showing change in Revenue, COS and EBIT

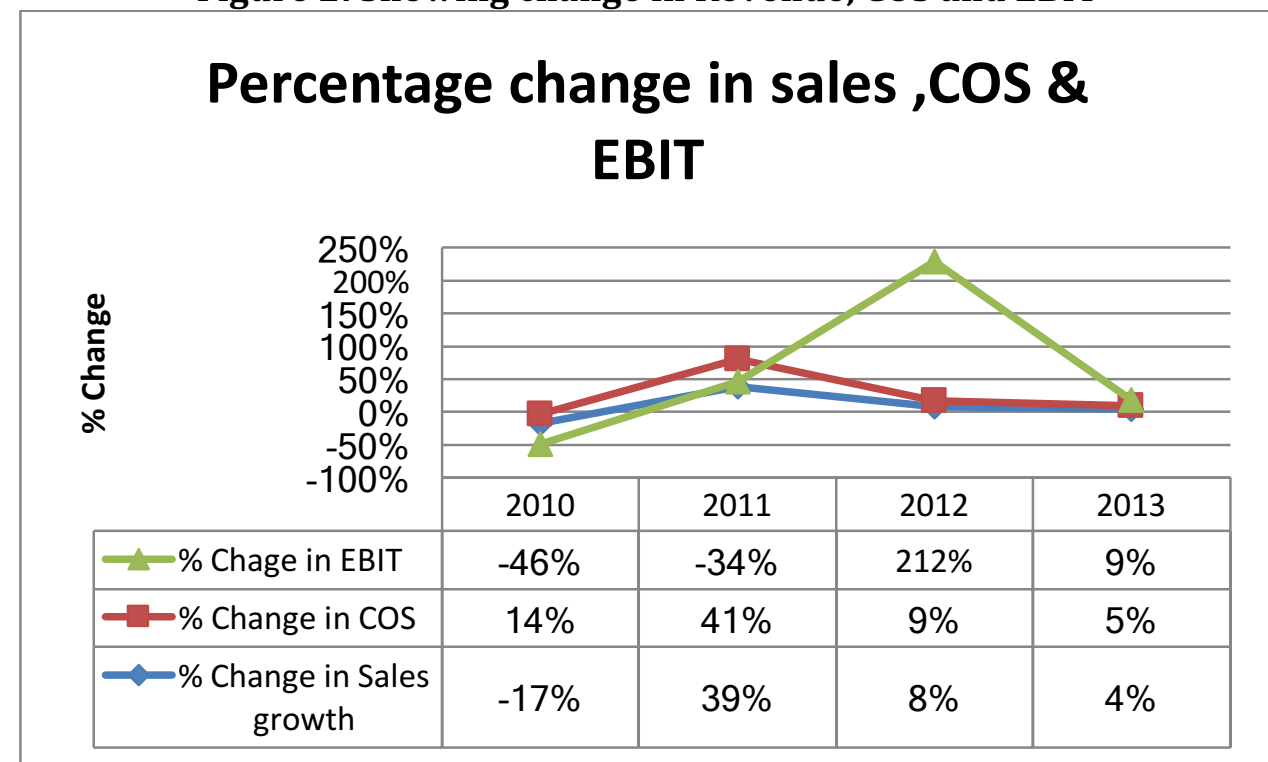

Source: Authors 
In order to reduce the risk, management may take decision based on future forecast to determine the optimum capital structure. The fixed costs could be reduced by outsourcing noncore services (Arellano and Scofield 2014).

\section{Systematic Risks}

Systematic risk is measured by beta ( $\beta$ ) representing the sensitivity of a company's returns compared to the market's returns. Beta greater than 1 tends to aggravate the volatility of returns to market movements, and beta of less than 1 indicates that the company's volatility moves in the same direction with the market (Brealey, Myers and Allen 2014). Wood Group's Beta is 1.73 (ft.com 21 March, 2015), while the beta of its peers, Amec Foster Wheeler Plc 1.21 and WS Atkins Plc 1.01 (ft.com 6 April 2015) as shown in figure 3. Therefore, WG's systematic risk appears to be high compared to the market. Figure 4 shows that during 2011 to 2013 Wood Group's beta seemed stable while in 2014 and 2015 it was volatile. This could be as a result of changes in oil and gas prices, interest rates and exchange rates, and inadequate information provided by the company to the market. Furthermore, the high beta values could have been due to high operating leverage which may have resulted to earnings variability as illustrated in figure 2 .

Figure 3: Shows Beta for WG and its peers

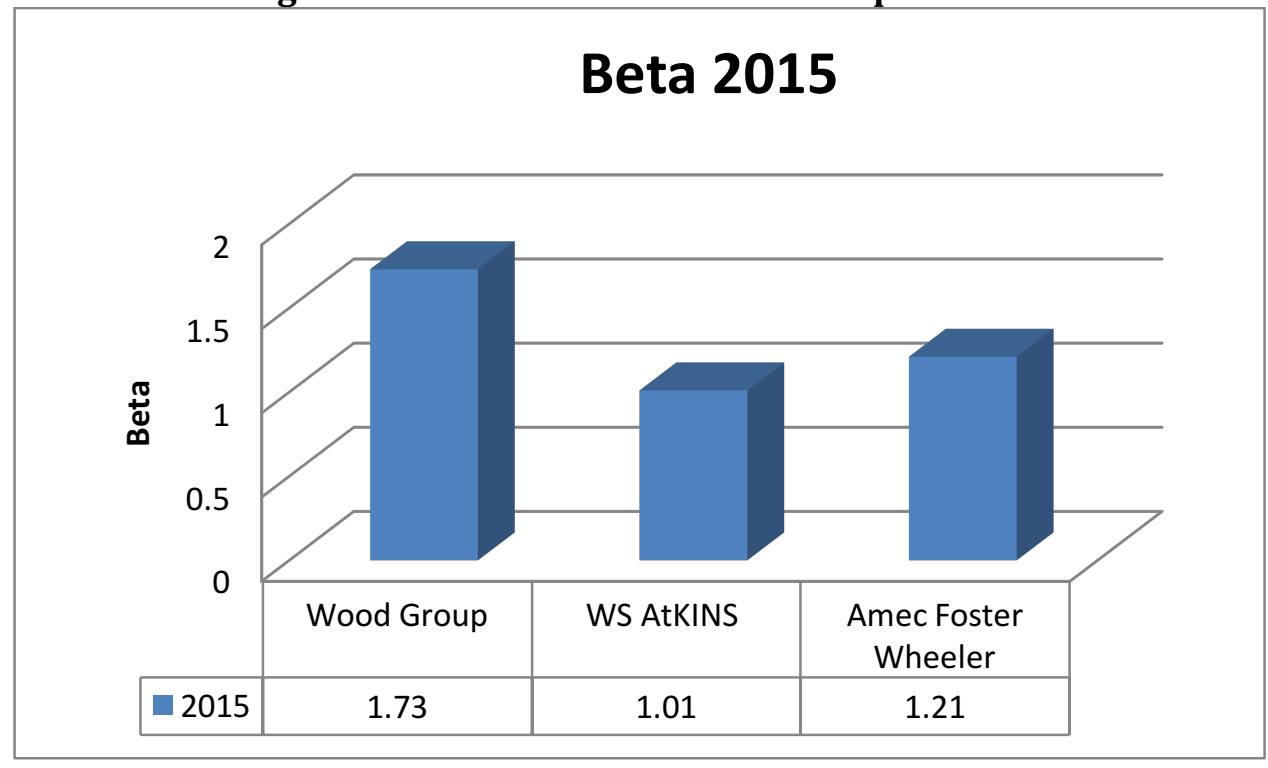

Source: Authors 
Figure 4: Shows WG Beta Trends 2011-2015

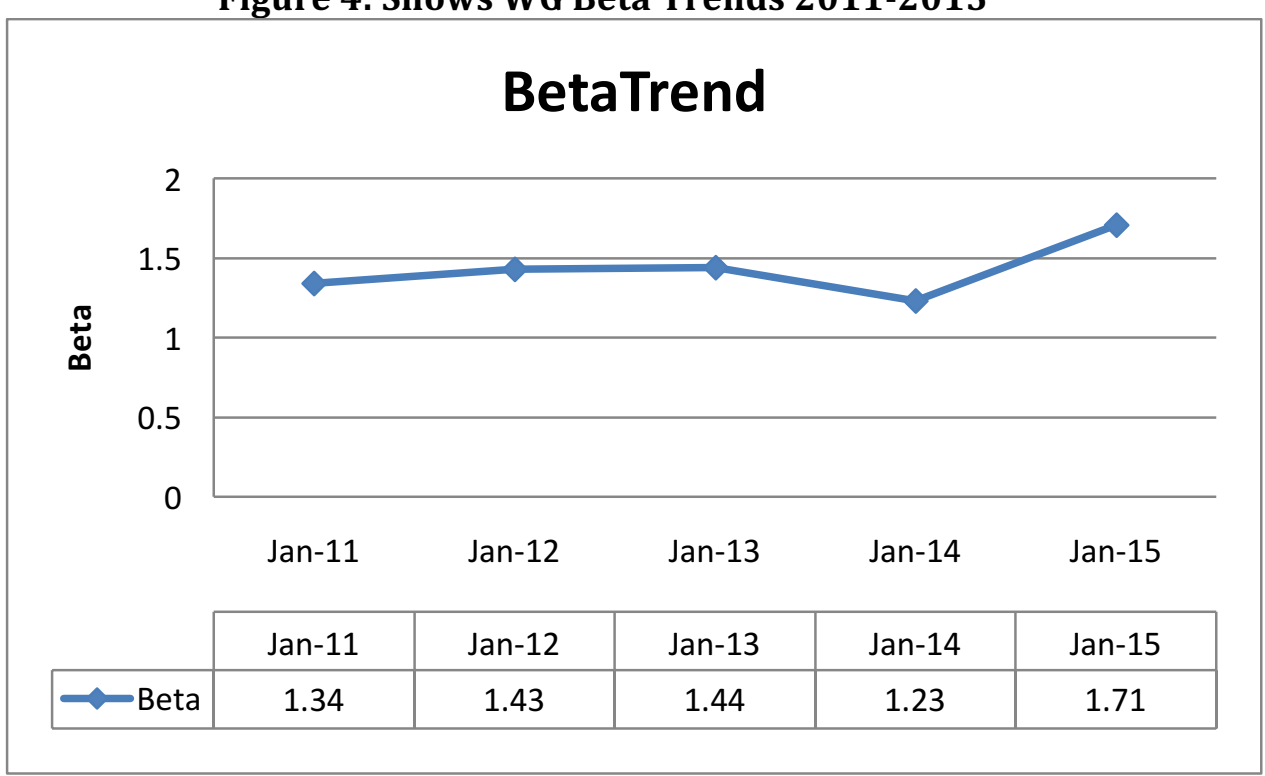

Source: Authors

However, management may mitigate the risk by maintaining low financial leverage and adequate disclosure of information.

\section{Financial Risk of the company}

Financial risk is determined by the degree of financial leverage (DFL). An increase in debt would lead to high financial leverage (Ghosh and Jain 2000). Wood Group's degree of financial Leverage is 1.06 while for its peers Amec Foster Wheeler Plc and WS Atkins Plc are 1.06 and 1.14 respectively. WG and its peers seem to have low financial risk since their DFL is close to 1 , as shown in Figure 5. Similarly Wood Group's proportion of Debt in its capital structure for the last five years has been below $26 \%$, indicating that the company is not highly geared. Therefore WG may not borrow additional funds due to high operating leverage and the current slump in oil prices which may reduce the demand for its services.

Figure 5: Shows Degree of Financial Leverage

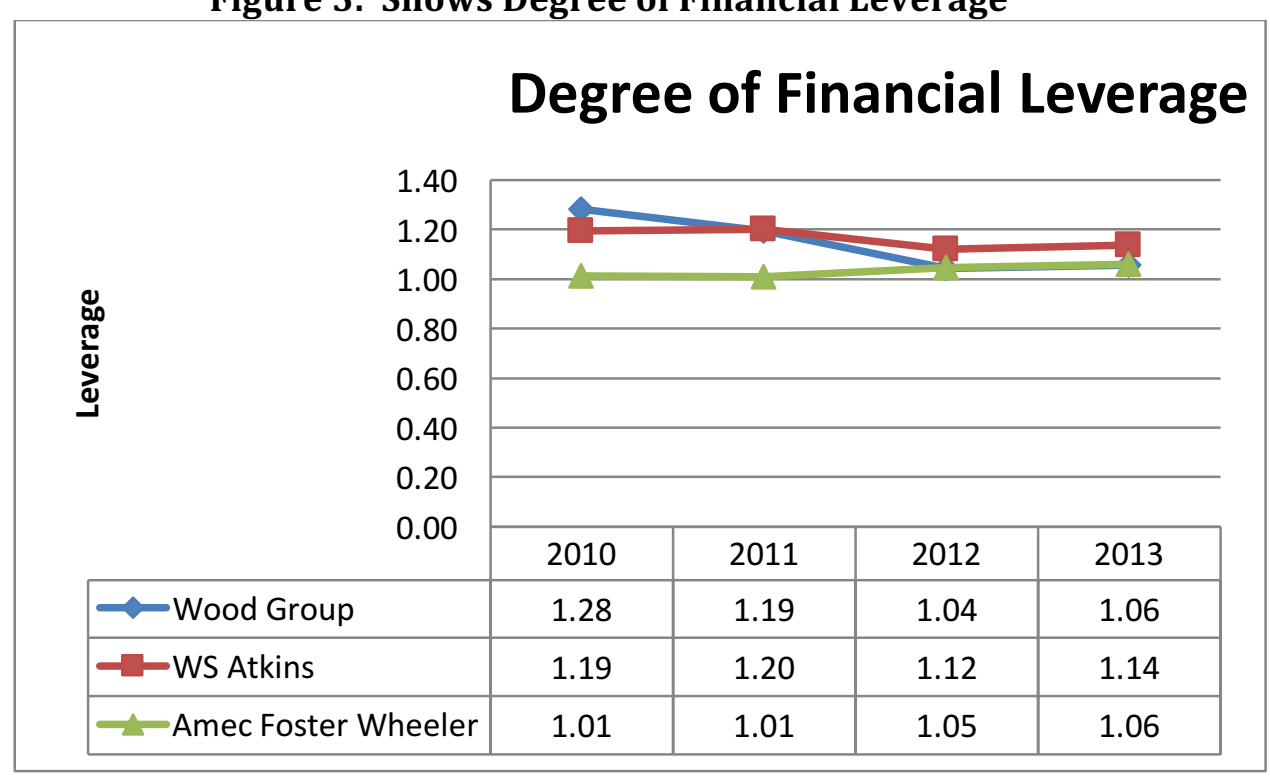

Source: Authors 


\section{Trend and Comparative analysis of Key Ratio}

This section covered a trend and comparative analysis of key ratios that highlight any key aspects of risk in Wood Group and its peers.

\section{Debt Ratio and Interest cover.}

Wood Group's Debt ratio has been stable since 2010 to 2013 in the range of 19\% to 22\%, similarly Amec Foster Wheeler Plc Debt ratio is stable within the ranges of $16 \%$ to $21 \%$, while WS Atkins Debt ratio is higher within the ranges of $72 \%$ to $120 \%$ (figure 6). The high debt ratio of $120 \%$ in 2010 was a result of retained loss of $£ 156.7 \mathrm{~m}$ (WS Atkins Annual Report 2010). Furthermore, Wood Group and its peers have the capacity to pay their finance costs based on the Interest cover ratio which is above 3times (figure 7). Since Wood Group maintains a low debt ratio, it can raise additional funds through debt during periods of boom.

Figure 6: Shows Debt Ratio

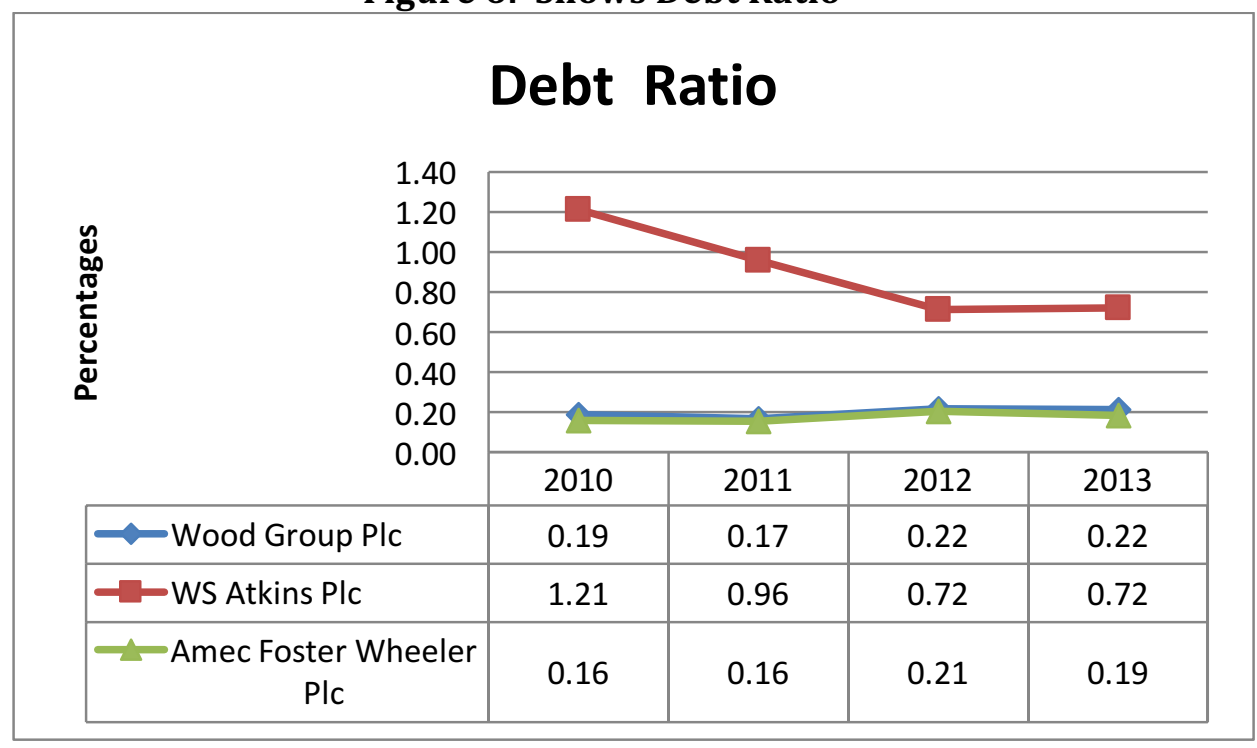

Source: Authors

Figure 7: Shows Interest Cover

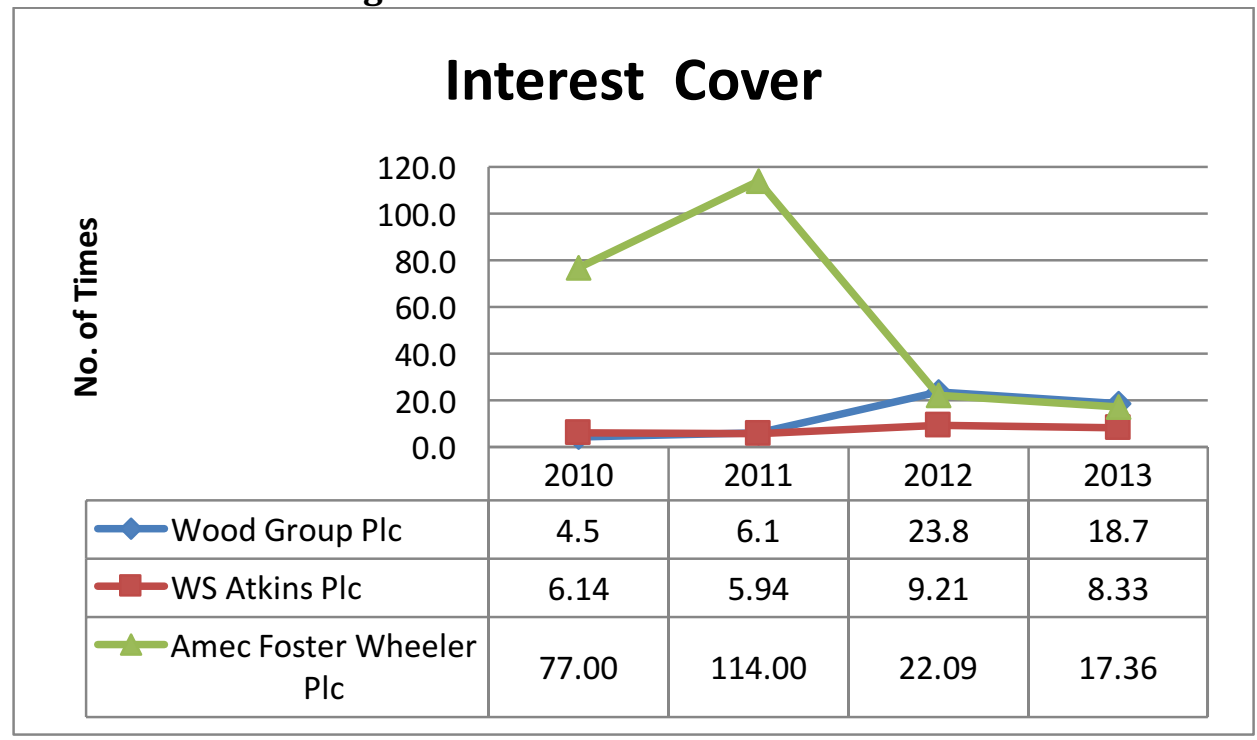

Source: Authors 


\section{Liquidity ratio- Current Ratio}

Wood Group's current ratio has been below 1 from the year 2010 to 2012, however there was improvement to 1.61 in 2013. In comparison, Wood Group's ratio was below its peers from 2010 to 2012. In 2013, it was above its peers Amec Foster Wheeler Plc 1.22 and WS Atkins 1.17 (figure 8). Wood Group's current ratio is above 1 implying that it would be able to finance its short-term obligations (Vernimmen et. al 2009).

Figure 8: Shows Current Ratio

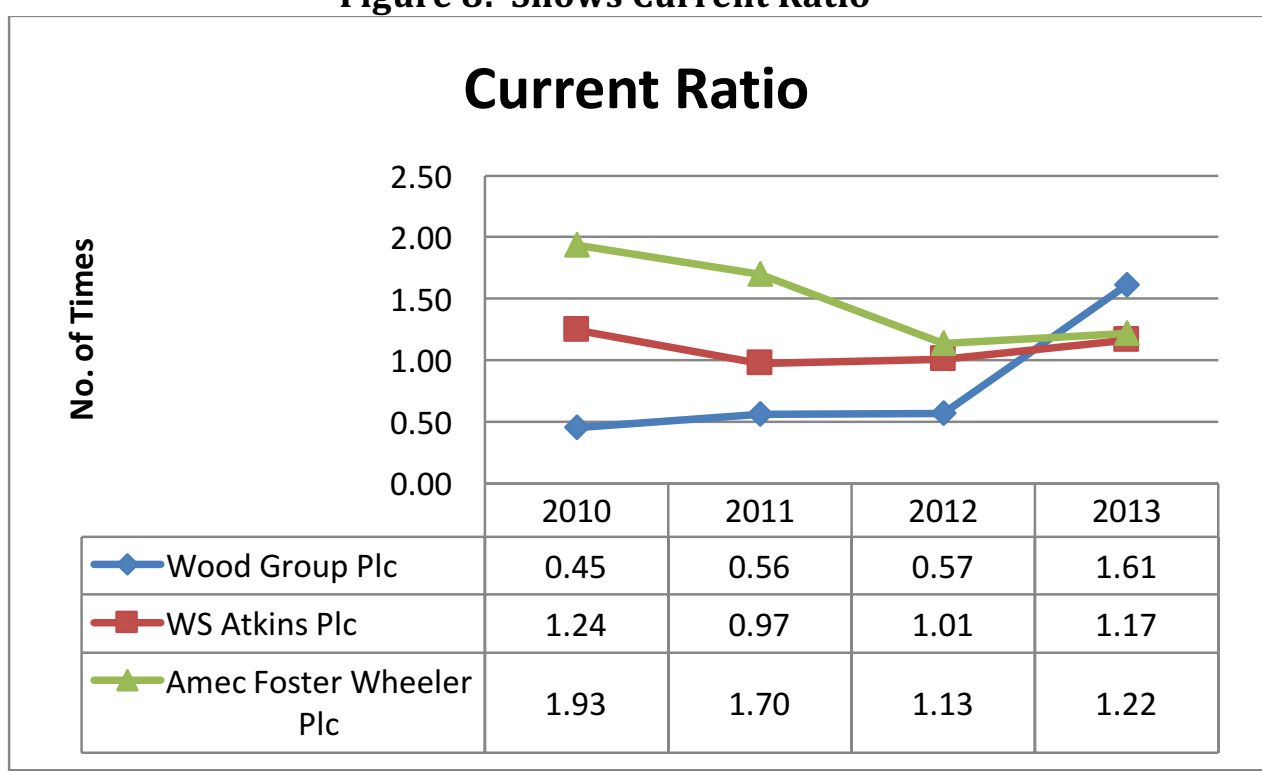

Source: Authors

\section{Efficiency Ratio- Asset Turnover}

A high asset turnover ratio implies that a company is able to efficiently utilise its assets to generate revenues, which may reduce business risk (Fairfield and Yohn 2001). Wood Group's assets turnover seems stable with an average ratio of 1.45 between 2010 and 2013. In comparison with its peers, the asset turnover ratio is within the range of 1.35 and 1.6 (figure 9). Therefore, WG's ratio of 1.45 indicates that the company has the capacity to turn its assets into cash.

Figure 9: Shows Asset Turnover Ratio

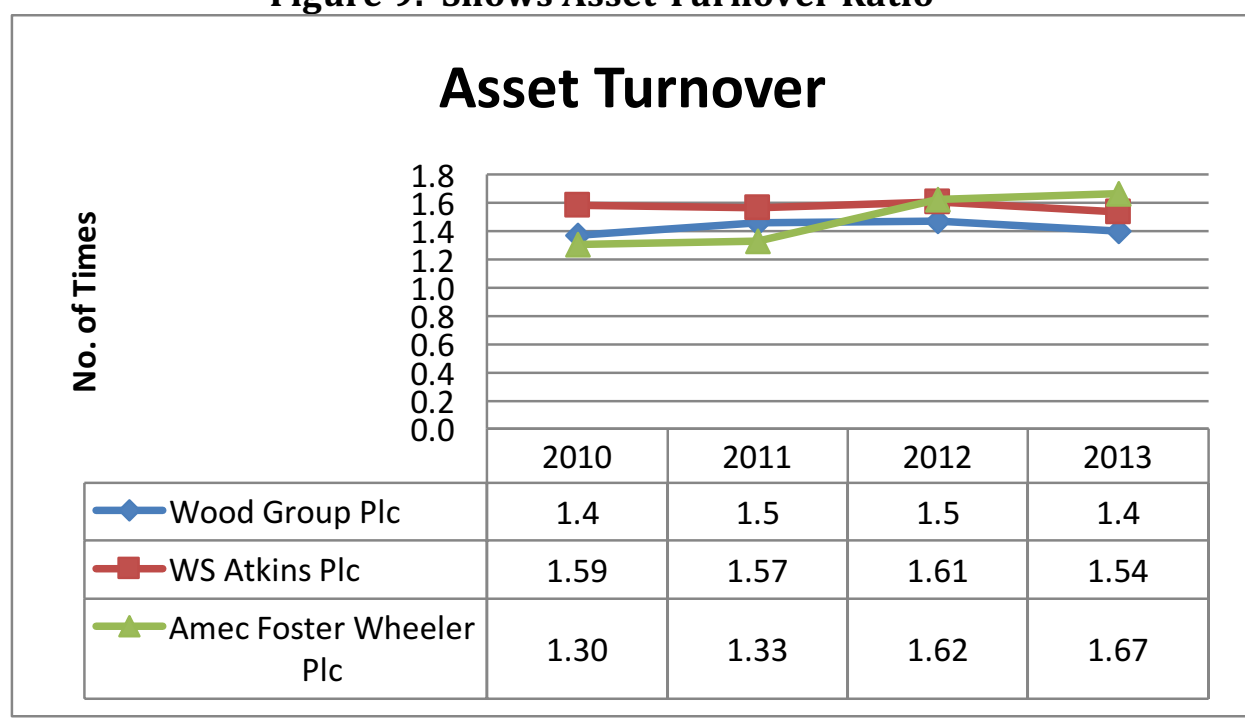

Source: Authors 


\section{Profitability Ratios}

\section{i. Net Profit Margin}

The Net Profit Margin of Wood Group improved from 1.04\% in 2011 to $4.28 \%$ in 2013 indicating a growth of $311 \%$. While the peers appear to have higher margin but they are declining as shown in figure 10 below. This implies that WG's results gives confidence to shareholders compared to the peers.

\section{Figure 10: Shows Net Profit Margin}

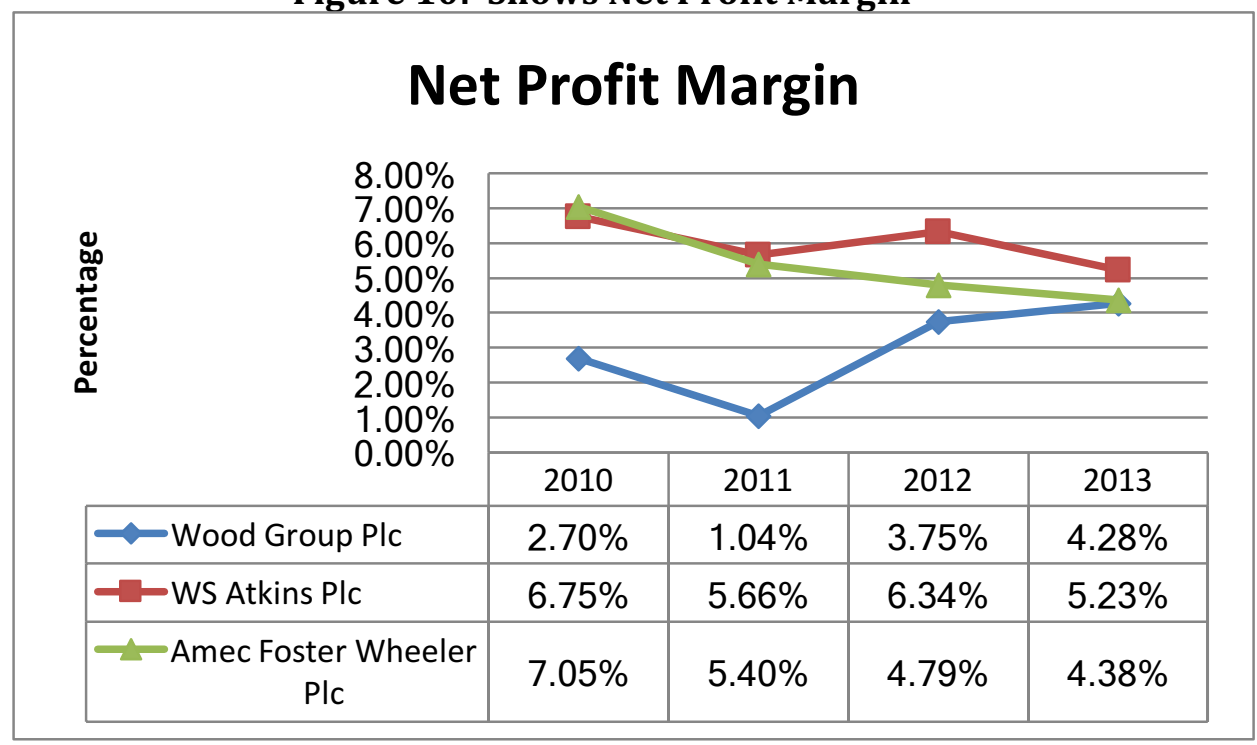

Source: Authors

\section{ii. Return on Assets (ROA)}

Wood Group's ROA improved from 3.7\% in 2010 to 6\% in 2013 meaning that the amount available to debt and equity investors per dollar of firm's assets improved over the years. In contrast, the ROA of its peers seem to be higher. The investors for WG may perceive that its peers have better return on assets. Hence vulnerable may divest their shares from WG.

Figure 11: Shows Return on Assets

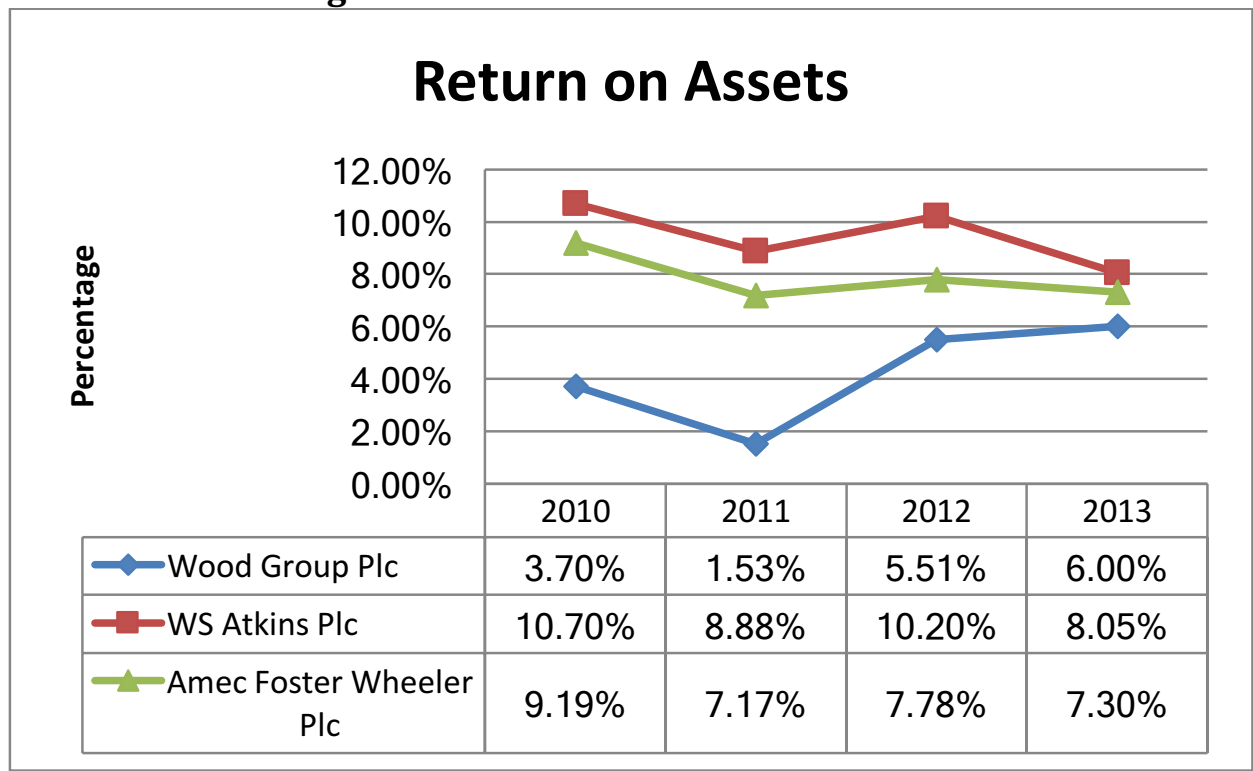

Source: Authors 


\section{iii. Returrn on Equity (ROE)}

Return on equity of WG shows a stable increase between $11 \%$ and $12 \%$ except in 2011 where it recorded an unsual increase of $116 \%$ due to income from discontinued operations of Well Support division and GTS Aero engine overhaul business (Wood Group's Annual Report and Accounts 2011 pg 21). WG's ROE is below the ROE of its peers (Figure 12), its shareholders may divest due to low returns.

Figure 12: Shows Return on Equity (ROE)

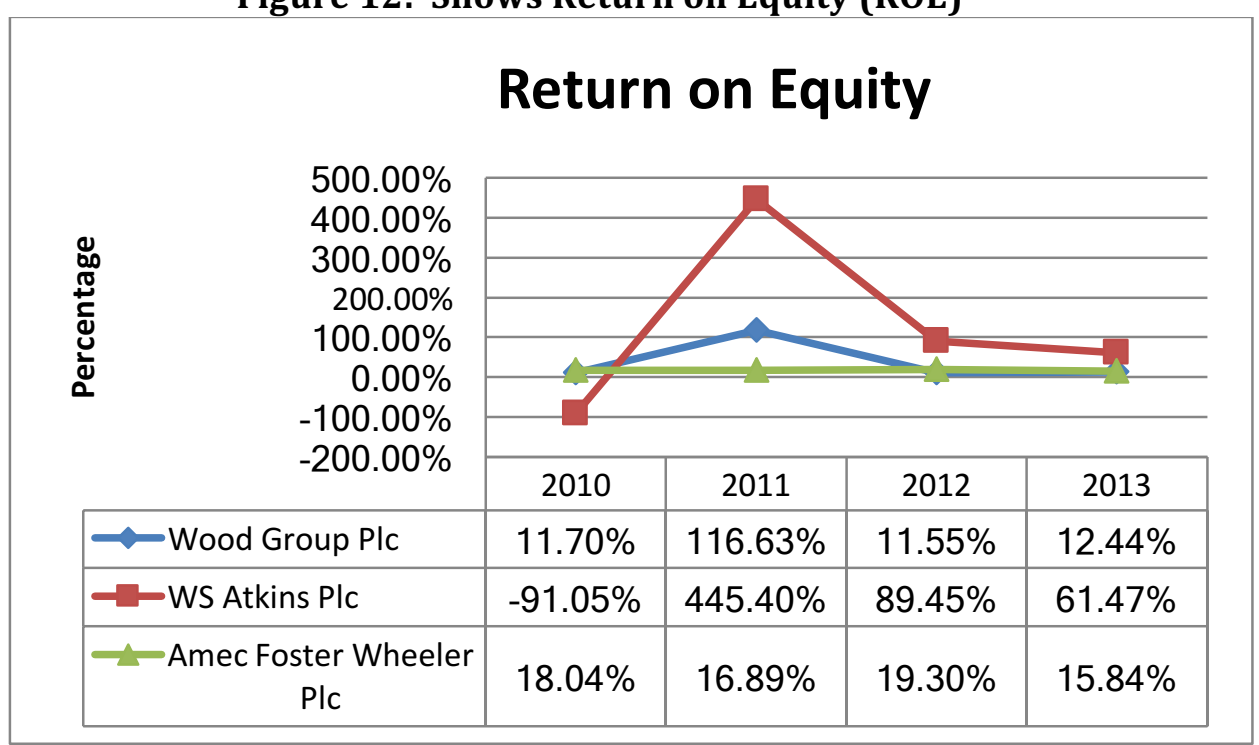

Source: Authors

\section{Sustainable Growth}

Wood Group's Sustainable growth ratio has been in the range of $7.95 \%$ to $9.65 \%$, except in 2011 an unusual growth was noted due to discontinued operations. Compared to its peers, Wood Group sustainable growth has been low, but the growth of the peers has been declining (figure 13). Therefore, WG's sustainable growth rate indicates that it can attain a 9\% growth without external sources, however, growth above $9 \%$ may require outside funding.

Figure 13: Shows Return on Equity (ROE)

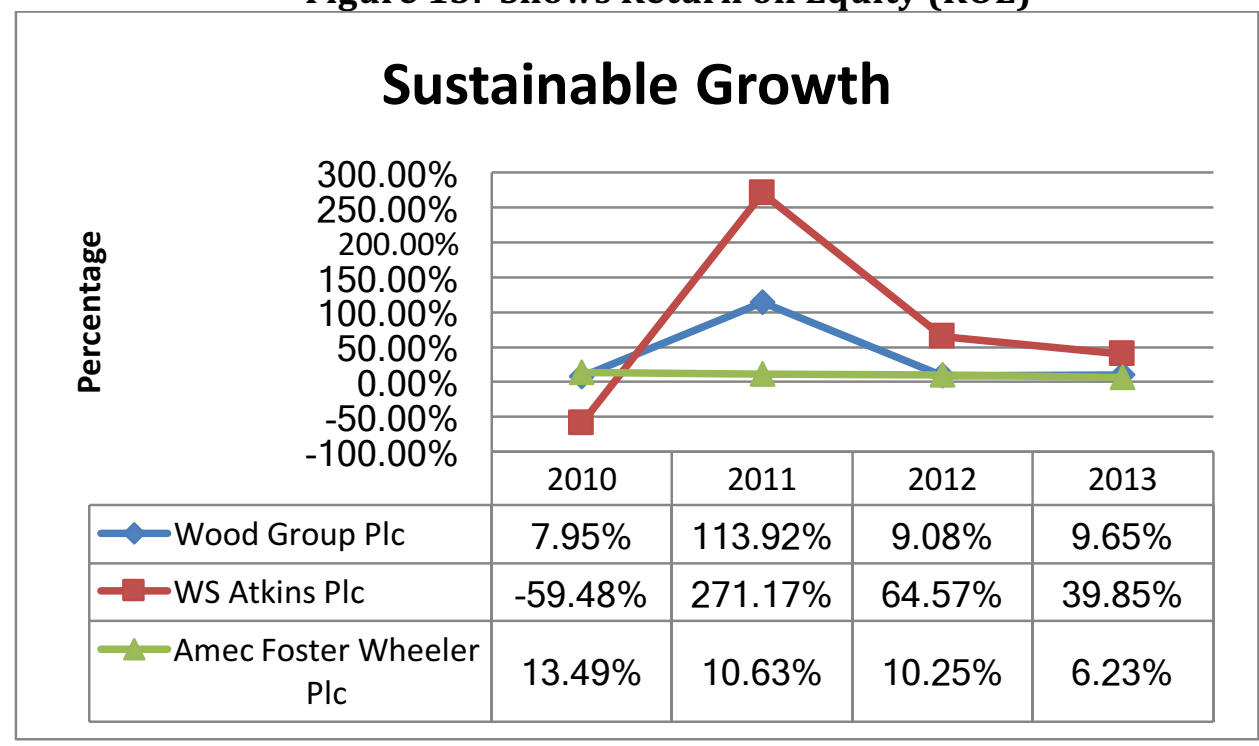

Source: Authors 


\section{Z-Score}

Wood Group's Z-score is above 2.6, which is the benchmark for a healthy company from 2010 to 2013. However, its peers appear to have maintained a $\mathrm{z}$-score below 1.1 and may be prone to corporate failure (figure 14). WG seems to be healthier than its peers and its not at risk of bankruptcy (Vernimmen et. al 2009).

Figure 14: Shows Z-Score

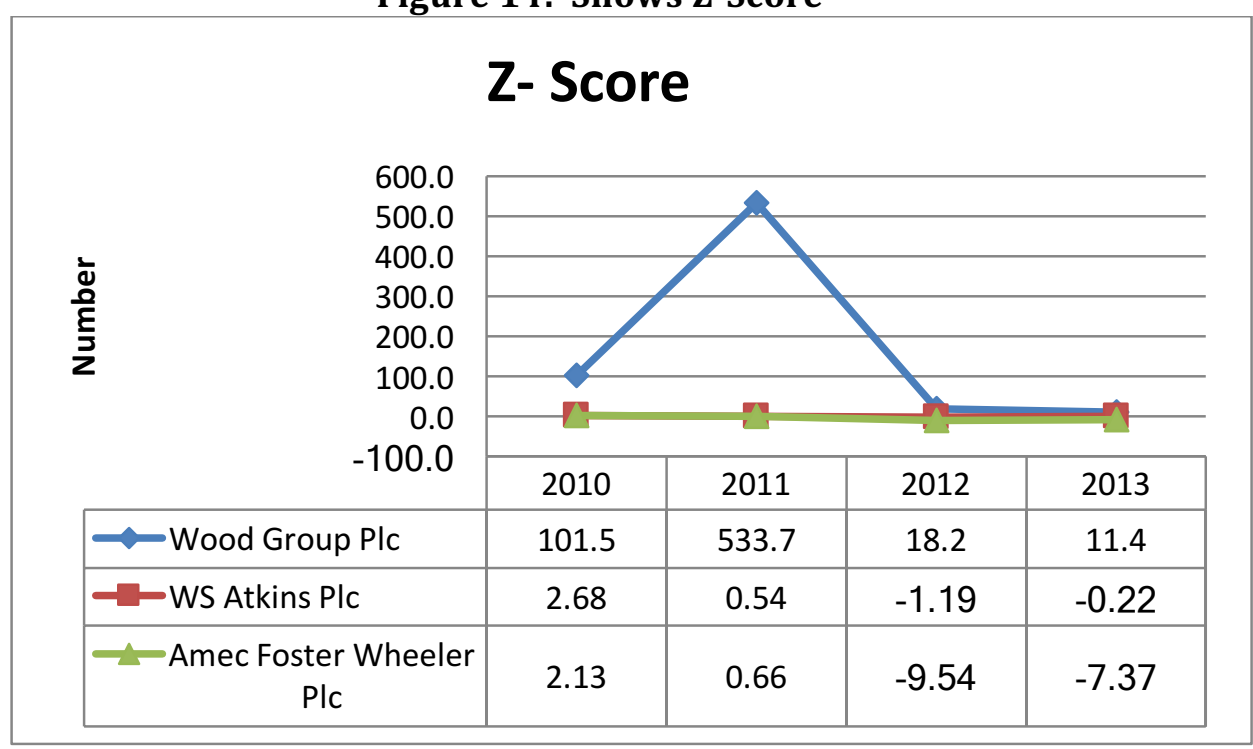

Source: Authors

\section{COMPANY VALUATION MODELS}

This section highlighted the various models of valuing Wood Group Plc.

\section{Net Asset Value Approach}

This approach indicates Wood Group's value is $\$ 2546$ while its market capitalisation is \$3656.62; it implies that Wood Group has been overvalued by 44\% (Appendix ii). The difference in value may be as a result of historical costs which do not recognise inflation, excludes internally generated intangible assets such as trademarks, brands and goodwill. However, the market capitalisation value may be affected by new information such as oil prices volatility. The overvaluation is good for WG but not favourable for investors.

\section{The Dividend Valuation Model}

This model gives WG a value of 912.12 cents, while the stock market price is 946.15 cents at a premium of $4 \%$ this means that Wood Group is overvalued (Appendix ii). The difference could be due to difficulty in estimating dividend growth rate and sometimes companies do not pay dividends. However, the current stock price may be affected by information available in the market and possibly positive investors' sentiments.

\section{The Price-Earnings Ratio approach}

This Approach gives the company a value of 1181.86 cents, while the current stock value is 946.15 cents at a discount of 20\% (appendix ii). This implies that Wood Group is undervalued. The difference may be as a result of new information in the market that affects the current stock price. However, the overvaluation may be due to use of sector average which includes companies in the same sector that may not be similar in size, performance and policies. 


\section{Rappaport's Shareholder Value Model}

This model revealed company's value of \$1455 against the market capitalisation of $\$ 3656.62$ resulting to a premium of $151.28 \%$ (Appendix iii). Wood Group is overvalued by the market. Hence, selling at premium is beneficial to WG but is not desirable to the buyer.

Table 1: Sensitivity \& Scenario Analysis

\begin{tabular}{|c|c|c|c|c|c|}
\hline $\begin{array}{l}\text { Value drivers for } \\
\text { Wood Group }\end{array}$ & $\begin{array}{l}\text { Base } \\
\text { Case }\end{array}$ & $\begin{array}{l}\text { Sensitivity } \\
\text { Analysis: } \\
\text { Change in } \\
\text { Revenue } \\
\text { Growth } \\
\text { Rate }\end{array}$ & $\begin{array}{l}\text { Sensitivity } \\
\text { Analysis: } \\
\text { Change in } \\
\text { Operating } \\
\text { Profit } \\
\text { Margin }\end{array}$ & $\begin{array}{l}\text { Scenario } \\
\text { Analysis }\end{array}$ & $\begin{array}{l}\text { What is } \\
\text { market } \\
\text { Factoring? }\end{array}$ \\
\hline $\begin{array}{l}\text { Annual Growth Rate in } \\
\text { Revenue \% }\end{array}$ & 0.1092 & 0.530 & 0.1092 & $\begin{array}{l}\text { Increased } \\
\text { Revenue }\end{array}$ & 0.22 \\
\hline $\begin{array}{l}\text { Operating Profit } \\
\text { Margin \% }\end{array}$ & 0.055 & 0.055 & 0.1 & $\begin{array}{l}\text { Increased } \\
\text { Operating } \\
\text { Margin }\end{array}$ & 0.09 \\
\hline Tax Rate & 0.28 & 0.28 & 0.28 & & 0.28 \\
\hline $\begin{array}{l}\text { Incremental Fixed } \\
\text { Capital Investment \% }\end{array}$ & 0.026 & 0.026 & 0.026 & & 0.026 \\
\hline $\begin{array}{l}\text { Incremental Working } \\
\text { Capital Investment \% }\end{array}$ & 0.120 & 0.120 & 0.120 & & 0.120 \\
\hline Planning Horizon & 5 years & 5 years & 5 years & & 5 years \\
\hline $\begin{array}{l}\text { Required Rate of } \\
\text { Return \% }\end{array}$ & 0.1954 & 0.1954 & 0.1954 & & 0.1954 \\
\hline $\begin{array}{l}\text { Rappaport's } \\
\text { Shareholder Value }\end{array}$ & 1455 & 3642 & 3630 & & 3629 \\
\hline $\begin{array}{l}\text { Market } \\
\text { Capitalisation }\end{array}$ & 3656.6 & 3656.62 & 3656.62 & & 3656.62 \\
\hline Premium/Discount & $151 \%$ & $0.4 \%$ & $0.7 \%$ & & $0.8 \%$ \\
\hline
\end{tabular}

The above table 1 indicates that a change in annual revenue growth rate from $10.92 \%$ to $53 \%$ resulted into a company value increase from $\$ 1455$ to $\$ 3642$ respectively, leading to a premium of $0.4 \%$. However, a change in operating profit margin from $5.5 \%$ to $10 \%$ resulted into company value of $\$ 3630$ yielding a premium of $0.7 \%$. Additional multi-variant sensitivity analysis indicates that a change in revenue growth rate to $22 \%$ and operating profit margin to $0.9 \%$ resulted into a value of $\$ 3629$ and a premium of $0.8 \%$. The Rappaport model of company valuation seems to be more sensitive to slight change in the operating profit margin than the annual revenue growth rate. The model assumes a smooth change in various cash flow drivers from one year to another. However, the market is not stable as market participants react differently to information available in the market, for example, changes in oil price and changes in senior management (Arnold 2013). More so, if used for target setting, managers can misuse it by pursuing short term cash flow objectives and avoid any investment which may result into long term cash flow. Nevertheless, it can be mitigated by setting both long term and short term cash flow targets (Arnold 2013).

\section{Selection of the Optimum Approach}

Among the models discussed above, the Dividend model gives the company a value of 912.12 cents, which is closer to the stock market price of 946.15 cents. The model seems to be to be forward looking in regards to its assumptions such as the dividend growth rate; it also considers time value for money through the discount rate. However, the challenge with the 
model is that forecasting future dividends is not straightforward and the growth does not occur as assumed, some companies use share buyback schemes which may not be reflected in the market, while other companies may not pay dividends in case of growing companies.

However, the other models did not give value closer to the market value possibly due to their assumptions. Net Asset value model uses historical costs and excludes internally generated intangible assets such as goodwill. Furthermore, the P/E multiple based valuation model may have been over valued due to use of sector average. Finally, the Rappaport Shareholder Value model assumes constant growth in cash flows and no growth in revenue after planning horizon.

\section{AGENCY RELATIONSHIP IN A FIRM}

Managers of a firm might sometimes take actions to benefit themselves at the expense of the firm's investors. Firms have put in place variety of mechanisms to mitigate agency problem (Edgerton 2012).

\section{Debt ratio}

Wood Group's average debt ratio of $22 \%$ seems to be low and this may lead to managers pursuing their own interest rather than shareholders' interests since there is no external pressure to pay fixed finance costs. WG seems to have the same debt ratio with Amec Foster Wheeler Plc but WS Atkins Plc has a higher debt ratio of 72\% in 2013 (Figure 6). The agency problem in WG may be mitigated by increasing its leverage by the use of debt, as debt imposes discipline to mangers on its own, this may push them to be more efficient (Vernimmen et. al 2009).

\section{Investments}

WG's investments include acquisitions of Duval and Mittchell in 2012, in 2013, the company made strategic acquisitions of $\$ 276 \mathrm{~m}$ including Elkhom in the US Shale market (WG's Annual Report 2013). These acquisitions could be influenced by the company's strategic objectives of rewarding and retaining executives. This is achieved by giving performance based incentives to managers to encourage creation of shareholders' value in the long-run. However, the fixed salary payments and bonuses may cause agency problems (Brealey, Myers and Allen 2014).

\section{Dividend Growth Policy}

Wood Group's dividend pay-out ratio in 2013 was 22\% which is below it peers of between $35 \%$ to $61 \%$ in 2013 (Figure 15). This could lead to agency problem as the management retains $78 \%$ of the year's earnings. Therefore, to reduce the problem, possibly, management could increase the dividend pay-out ratio, on the other hand this could also lead to conflict between the shareholders and the creditors when the dividend paid out is significant (Vernimmen et. al 2009) 


\section{Figure 15: Shows Dividend Pay-Out Ratio}

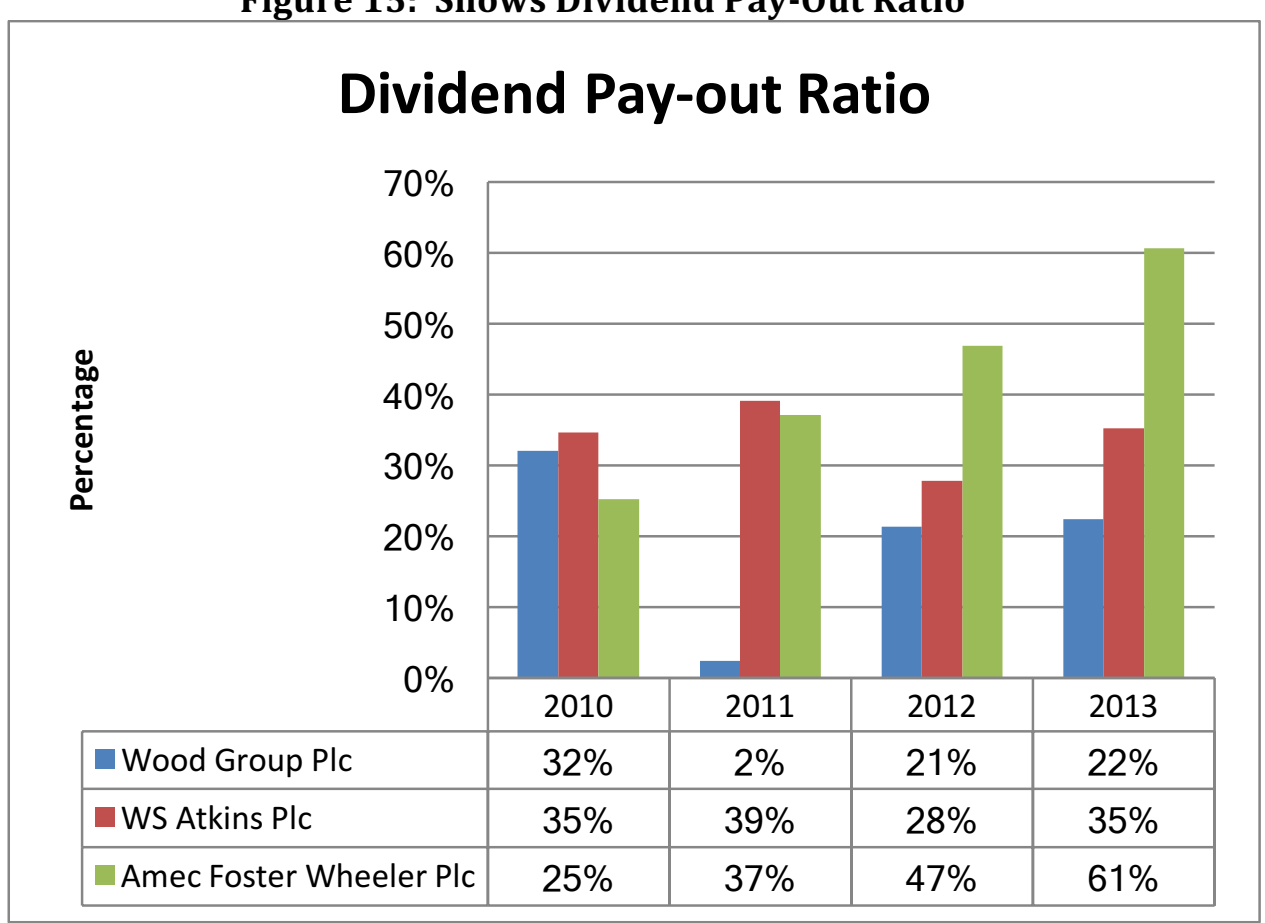

Source: Authors

\section{Cash Management}

Wood Group holds $\$ 183.5 \mathrm{~m}$ of cash at bank and in hand in 2013 which represent $20.6 \%$ of the total working capital, too much cash at the management disposal leads to agency problem. Holding cash may be affected by inflation and saving excess cash yields the lowest return. The cash could have been invested in short term marketable securities, which could generate a return to the shareholders.

\section{Revenue Growth Rate}

Wood Group's revenue growth rate declines from 38\% in 2011 to $4.27 \%$ in 2013 (figure 2) This may be an agency problem as continuous decline in the growth rate may result into uncertainty of shareholders returns, hence conflict between shareholders and management. This could be mitigated by improving the revenue growth through increasing market share, acquisitions and advertising. (Arnold 2013).

\section{Operating Profit Margin}

Wood Group's operating profit margin seems unstable for the last 3 years from 2010 to 2012 and below its peers, However in 2013 the company's operating profit is similar to its peers at $6 \%$ as shown in figure below

A low operation profit margin is an indicator of business risk and this causes concerns for Investor and may result into agency problems.

Management may mitigate this problem by improving its revenue and reducing costs. 
Figure 16: Shows Operating Profit Margin

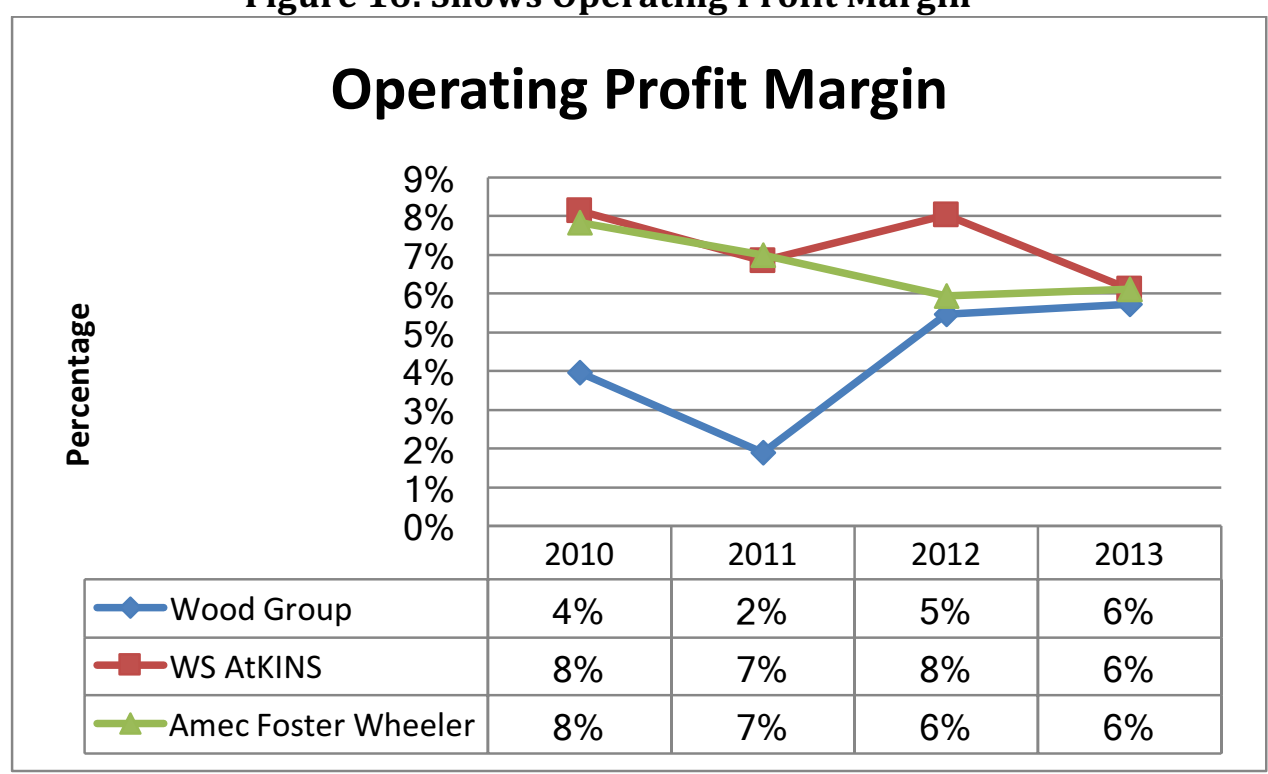

Source: Authors

\section{Asset Utilisation}

Wood Group's Asset turnover has been stable in the past 3years in the ranges of 1.5, however in 2013 it declined to 1.4\%, in comparison to its peers WG's asset utilisation has been below over the 4 years as shown in figure 9. This may cause Agency issues in a firm as management may be perceived by shareholders as not utilising assets efficiently. Management may consider identifying underperforming assets and disposing them off.

\section{Composition of the Board of Directors}

Shareholders expect management to champion their interests, but sometimes managers may focus on their own interests. WG is composed of 13 board members out of these $8(62 \%)$ are non-executive directors and $5(38 \%)$ are executive directors. This is below its competitors as shown in figure 17. Having a low number of non-executive directors may result to agency problem, as opposed to the Sarbanes-oxley Act that requires corporations to increase the number of non-executive directors to three-quarters of the total number of directors (Brealey, Myers and Allen 2014). 
Figure 17: Shows Board Composition

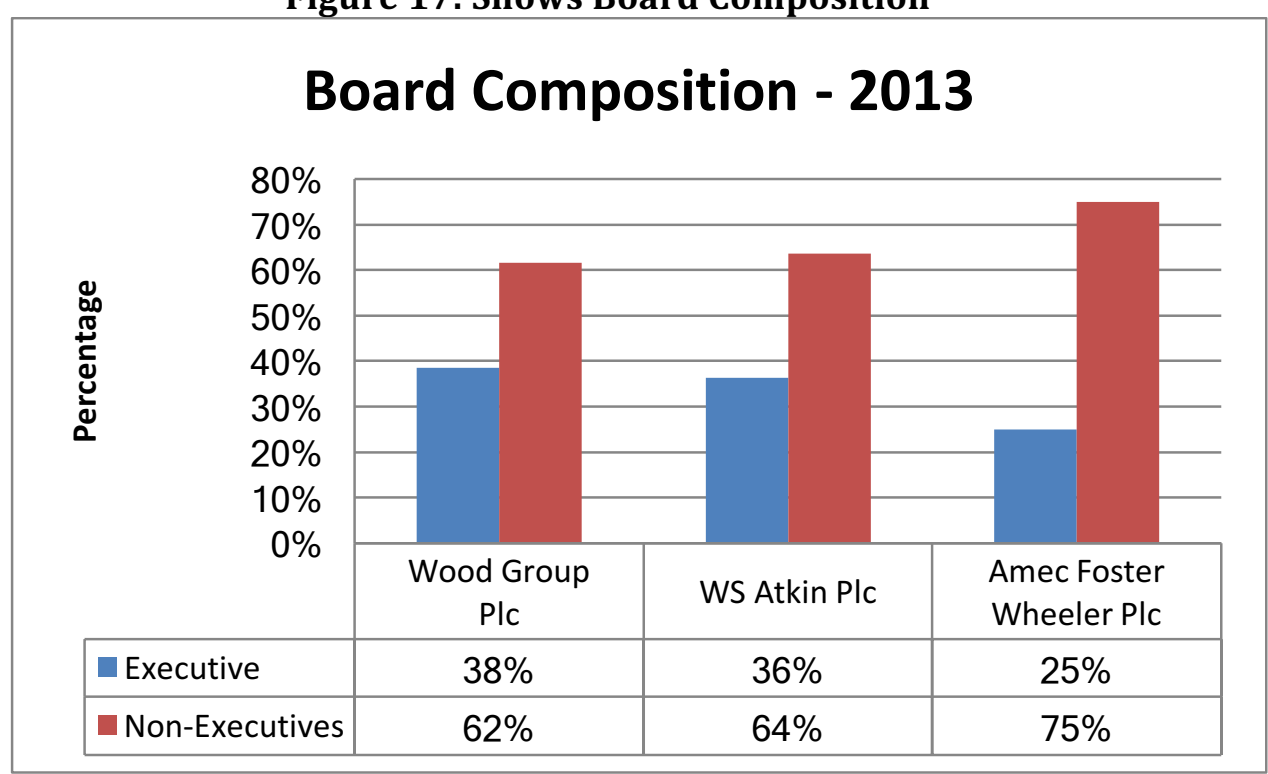

Source: Authors

\section{Empire Building}

Managers may prefer controlling large businesses by expanding the company beyond its optimal size, with an intention to obtain personal utility, power and prestige (Chen, Lu and Sougiannis 2012). For example Wood Group made a number of acquisitions such as PSN in 2011, Duval and Mittchell in 2012, and Elkhom in 2013 (WG's Annual Report 2013). This may create future Agency problems between managers and shareholders. This problem could be resolved by constituting strong corporate governance practice. Managers could be encouraged to invest in convertible bonds which give them part of ownership of the company.

\section{CONCLUSION}

In conclusion this report considered Wood Groups risk profile analysis, company valuation and agency issues. From the above report WGs business risk and systematic risk were high while its financial risk was low. Furthermore the report found that the dividend valuation model value was closest to the market value. Finally it also analysed the past and possible future agency problems.

\section{References}

Amec Foster Wheeler Plc 2010-2013. Annual report and Accounts, London

ARELLANO, F. and SCOFIELD, B., 2014. A Ratio-Based Equation for Operating Leverage. Academy of Accounting \& Financial Studies Journal, 18(4), pp. 1-3

BREALEY, R.A., MYERS, S.C. and ALLEN, F., 2014. Principles of corporate finance. 11th, Global ed. New York: McGraw-Hill Irwin.

CHEN, C.X., LU, H. and SOUGIANNIS, T., 2012. The Agency Problem, Corporate Governance, and the Asymmetrical Behavior of Selling, General, and Administrative Costs. Contemporary Accounting Research, 29(1), pp. $252-282$

EDGERTON, J., 2012. Agency Problems in Public Firms: Evidence from Corporate Jets in Leveraged Buyouts. Journal of Finance, 67(6), pp. 2187-2213

FAIRFIELD, P.M. and YOHN, T.L., 2001. Using asset turnover and profit margin to forecast changes in profitability. Review of Accounting Studies, 6(4), pp. 371-385

GHOSH, A. and JAIN, P.C., 2000. Financial leverage changes associated with corporate mergers. Journal of Corporate Finance, 6(4), pp. 377-402

John Wood Group Plc 2010-2013. Annual Report \& Accounts, Aberdeen 
MASULIS, R.W. and REZA, S.W., 2015. Agency Problems of Corporate Philanthropy. Review of Financial Studies, 28(2), pp. 592-636

VERNIMMEN, P. and QUIRY, P., 2009. Corporate finance: theory and practice. 2nd ed. Chichester: Wiley.

WS Atkins Plc 2010-2013. Annual Report and Accounts, London

\section{Appendix i}

\begin{tabular}{|c|c|c|c|c|c|}
\hline WOOD GROUP & $\begin{array}{l}\text { Risk Profile } \\
\text { (Accounting } \\
\text { Based) }\end{array}$ & & & & \\
\hline & 2009 & 2010 & 2011 & 2012 & 2013 \\
\hline & $\$(\mathrm{mn})$ & $\$(\mathrm{mn})$ & $\$(\mathrm{mn})$ & $\$(\mathrm{mn})$ & $\$(\mathrm{mn})$ \\
\hline Revenue & 4927.1 & 4085.1 & 5666.8 & 6118.4 & 6379.7 \\
\hline Growth in Sales & & $17.09 \%$ & $38.72 \%$ & $7.97 \%$ & $4.27 \%$ \\
\hline Cost of Sales & 3870.1 & 3332.5 & 4713.1 & 5118.5 & 5351.9 \\
\hline Operating Profit & 298.5 & 162.1 & 107.5 & 335.0 & 365.6 \\
\hline $\begin{array}{l}\text { E.B.I.T (Same as operating } \\
\text { profit) }\end{array}$ & 298.5 & 162.1 & 107.5 & 335.0 & 365.6 \\
\hline Interest Paid & 36.2 & 35.8 & 17.5 & 14.1 & 19.6 \\
\hline Taxes & 100.6 & 51.7 & 48.3 & 105.7 & 92.6 \\
\hline Net Income (million) \$ & 164.2 & 165.8 & 2302.8 & 258.2 & 300.5 \\
\hline EPS (cents) Annual Report & 31.20 & 31.30 & 513.00 & 69.0 & 79.2 \\
\hline Retained Earnings & 877.60 & 1007.60 & 1469.80 & 1640.7 & 1856.6 \\
\hline Dividends (million) \$ & 50.3 & 53.1 & 53.4 & 55.2 & 67.4 \\
\hline Inventory & 618.9 & 663.8 & 404.5 & 439.5 & 101.1 \\
\hline Trade and other Receivables & 987.40 & 1052.0 & 1320.9 & 1392.5 & 1365.1 \\
\hline Cash and cash Equivalents & 208.6 & 180.1 & 226.6 & 172.3 & 183.5 \\
\hline Current Assets & 1850.7 & 1921.1 & 2007.1 & 2029.3 & 2356.0 \\
\hline Non Current (Fixed) Assets & 1003.8 & 1059.4 & 1873.9 & 2131.8 & 2192.0 \\
\hline Total Assets (million) \$ & 2854.5 & 2980.5 & 3881.0 & 4161.1 & 4548.0 \\
\hline Current Liabilities & 1137.1 & 1230.7 & 1605.2 & 1303.4 & 1466.5 \\
\hline Trade and other Payables & 1061.8 & 1139.8 & 1286.2 & 1155.8 & 1123.0 \\
\hline Non-Current Liabilities & 436.4 & 332.6 & 401.3 & 622.4 & 665.2 \\
\hline Total Liabilities & 1573.5 & 1563.3 & 2006.5 & 1925.8 & 2131.7 \\
\hline Net Debt & 87.9 & 15.1 & 3.9 & 154.5 & 309.5 \\
\hline Shareholders Funds (Equity) & 1281.0 & 1417.2 & 1974.50 & 2235.3 & 2416.3 \\
\hline \multicolumn{6}{|l|}{ Volatility Measures } \\
\hline$\%$ Change in Sales & & $17.09 \%$ & $38.72 \%$ & $7.97 \%$ & $4.27 \%$ \\
\hline \% Change in EBIT & & $45.70 \%$ & $-33.68 \%$ & $211.63 \%$ & $9.13 \%$ \\
\hline \% Change in EPS & & $0.32 \%$ & $1538.98 \%$ & $-86.55 \%$ & $14.78 \%$ \\
\hline \multicolumn{6}{|l|}{ Key Risk Indicators } \\
\hline Degree of Operating Leverage & & 2.67 & -0.87 & 26.56 & 2.14 \\
\hline $\begin{array}{l}\text { Degree of Financial Leverage } \\
\text { DFL }=\{\text { EBIT } /(\text { EBIT-Interst) }\}\end{array}$ & & 1.28 & 1.19 & 1.04 & 1.06 \\
\hline Degree of Total Leverage & & -0.02 & 39.75 & -10.86 & 3.46 \\
\hline
\end{tabular}




\begin{tabular}{|c|c|c|c|c|c|}
\hline \multicolumn{6}{|l|}{$\begin{array}{l}\text { Capital Structure and } \\
\text { Financing Risk }\end{array}$} \\
\hline Debt Ratio & 0.25 & 0.19 & 0.17 & 0.22 & 0.22 \\
\hline $\begin{array}{l}\text { Debt Service or Interest Cover } \\
\text { (times) }\end{array}$ & 8.2 & 4.5 & 6.1 & 23.8 & 18.7 \\
\hline Current Ratio & 0.43 & 0.45 & 0.56 & 0.57 & 1.61 \\
\hline Working Capital & 713.60 & 690.40 & 401.90 & 725.90 & 889.50 \\
\hline \multicolumn{6}{|l|}{ Activity Indicators } \\
\hline Inventory Turnover (times) & 6.3 & 5.0 & 11.7 & 11.6 & 52.9 \\
\hline Asset Turnover (times) & 1.7 & 1.4 & 1.5 & 1.5 & 1.4 \\
\hline & & & & & \\
\hline \multicolumn{6}{|l|}{ Profitability Ratios } \\
\hline Return on Assets (ROA) & $6.93 \%$ & $3.70 \%$ & $1.53 \%$ & $5.51 \%$ & $6.00 \%$ \\
\hline \% Change in ROA & & -0.47 & -0.59 & 2.61 & 0.09 \\
\hline Net Profit Margin & $4.02 \%$ & $2.70 \%$ & $1.04 \%$ & $3.75 \%$ & $4.28 \%$ \\
\hline Operating profit Margin & $6 \%$ & $4 \%$ & $2 \%$ & $5 \%$ & $6 \%$ \\
\hline \multicolumn{6}{|l|}{ DuPont Analysis } \\
\hline DuPont ROA & $6.93 \%$ & $3.70 \%$ & $1.53 \%$ & $5.51 \%$ & $6.00 \%$ \\
\hline Return on Equity (ROE) & $12.82 \%$ & $11.70 \%$ & $116.63 \%$ & $11.55 \%$ & $12.44 \%$ \\
\hline Net Profit Margin & $4.02 \%$ & $2.70 \%$ & $1.04 \%$ & $3.75 \%$ & $4.28 \%$ \\
\hline Asset Turnover (times) & 1.73 & 1.37 & 1.46 & 1.47 & 1.40 \\
\hline Leverage Ratio & 2.23 & 2.10 & 1.97 & 1.86 & 1.88 \\
\hline Debt Burden & 0.82 & 0.68 & 0.70 & 0.94 & 0.93 \\
\hline DuPont ROE & $12.62 \%$ & $5.26 \%$ & $2.11 \%$ & $9.63 \%$ & $10.49 \%$ \\
\hline Plowback Ratio & $69 \%$ & $68 \%$ & $98 \%$ & $79 \%$ & $78 \%$ \\
\hline Dividend Pay-out ratio & $31 \%$ & $32 \%$ & $2 \%$ & $21 \%$ & $22 \%$ \\
\hline Z-Score & 18.6 & 101.5 & 533.7 & 18.2 & 11.4 \\
\hline & & & & & \\
\hline SUSTAINABLE GROWTH Rate & $8.89 \%$ & $7.95 \%$ & $113.92 \%$ & $9.08 \%$ & $9.65 \%$ \\
\hline
\end{tabular}




\section{Appendix ii}

\begin{tabular}{|c|c|}
\hline Wood Group plc & March-31-2015 \\
\hline Current Stock Price (cents) digitallook.com & 946.15 \\
\hline Latest annual EPS (cents) (digitallook.com 31/3/2015) & 98.9 \\
\hline Wood Group's P/E Ratio digitallook.com 31/3/15 & 10.5 \\
\hline Sector Average (See details on WG sector average worksheet) & 11.95 \\
\hline P/E multiple based Valuation & 1181.86 \\
\hline Discount/Premium & $-20 \%$ \\
\hline Last Dividend (cents) (digitallook.com) 31/3/2015 & 27.5 \\
\hline Required Rate of Return on WG's Equity (using CAPM) & $19.93 \%$ \\
\hline Dividend Growth Rate (ft.com) & $16.42 \%$ \\
\hline Dividend Growth Model based Valuation & 912.12 \\
\hline Discount/Premium & $4 \%$ \\
\hline Total Assets (\$ million) ft.com & 4387 \\
\hline Total Liabilities (\$ million) ft.com & 1841 \\
\hline Market Capitalisation ( $\$$ million) (ft.com) & 3656.62 \\
\hline Net Asset Value Model based Valuation & 2546 \\
\hline Discount/Premium & $44 \%$ \\
\hline
\end{tabular}




\section{Appendix iii}

\begin{tabular}{|c|c|c|c|c|c|c|c|}
\hline \multicolumn{8}{|l|}{ Wood Group Plc } \\
\hline \multicolumn{8}{|l|}{$\begin{array}{l}\text { Rappaport Shareholder Value } \\
\text { Model }\end{array}$} \\
\hline \multicolumn{8}{|l|}{ Value drivers for Wood Group } \\
\hline Annual Growth Rate in Sales \% & 0.1092 & & & & & & \\
\hline Operating Profit Margin \% & 0.055 & & & & & & \\
\hline Taxes $\%$ & 0.28 & & & & & & \\
\hline Incremental Fixed Capital Investment \% & 0.026 & & & & & & \\
\hline Incremental Working Capital Invstment \% & 0.120 & & & & & & \\
\hline Planning Horizon & 5 years & & & & & & \\
\hline Required Rate of Return (Appendix iv) & 0.1954 & & & & & & \\
\hline \multicolumn{8}{|l|}{ Other details } \\
\hline Current Sales (2014) (\$m) & 6574.1 & & & & & & \\
\hline Current Value of Marketable Securities (\$m) & 183.5 & & & & & & \\
\hline Net Debt $(\$ m)$ & 309.5 & & & & & & \\
\hline Forecasted Cash Flows (\$m) & & Y1 & Y2 & Y3 & Y4 & Y5 & $\begin{array}{c}\text { A.P. } \\
\text { Horizon }\end{array}$ \\
\hline Year & 2014 & 2015 & 2016 & 2017 & 2018 & 2019 & 2020 \\
\hline Sales & 6574.1 & 7292 & 8088 & 8972 & 9951 & 11038 & 11038 \\
\hline Operating Profit & & 401.1 & 444.9 & 493.4 & 547.3 & 607.1 & 607.1 \\
\hline Taxes & & 112.5 & 124.8 & 138.4 & 153.5 & 170.3 & 170.3 \\
\hline Incremental Fixed Capital Investment & & 18.7 & 20.7 & 23.0 & 25.5 & 28.3 & 0 \\
\hline Incremental Working Capital Invstment & & 86.1 & 95.6 & 106.0 & 117.6 & 130.4 & 0 \\
\hline Operating Free Cashflows & & 183.8 & 203.8 & 226.1 & 250.8 & 278.1 & 436.8 \\
\hline Present Value of Perpetuiy (after P. Horizon) & & & & & & & 2235.4 \\
\hline Discount Factor & & 0.84 & 0.70 & 0.59 & 0.49 & 0.41 & 0.41 \\
\hline Discounted Operating Free Cash Flows & & 153.71 & 142.63 & 132.35 & 122.80 & 113.95 & 915.77 \\
\hline $\begin{array}{l}\text { Present Value of the Free Cash Flows Within the } \\
\text { Planning Horizon }\end{array}$ & & & & & & & 665.44 \\
\hline $\begin{array}{l}\text { Present Value of the Free Cash Flows After the } \\
\text { Planning Horizon }\end{array}$ & & & & & & & 915.77 \\
\hline Present Value of Free Cash Flows from Operations & & & & & & & 1581.21 \\
\hline & & & & & & & \\
\hline Rappaport's Shareholder Value & & & & & & & 1455 \\
\hline Market Capitalisation (March 2015) & & & & & & & 3656.62 \\
\hline Premium/Discount & & & & & & & $151.28 \%$ \\
\hline
\end{tabular}




\section{Appendix iv \\ Wood Group Plc WACC}

\section{Cost of Equity}

WG Beta (21 March 15) source: FT.com

FTSE-All Return (long-term Average)

Risk-free Rate (5-year Gilt) \%, source:FT.com 28 March 2015

Required rate of Return or Cost of WG's equity using CAPM

\section{Cost of Debt}

Cost of Debt \%

Corporate Tax rate

After tax Cost of Debt

Market Values of Debt and Equity

Market Value of Debt Long term borrowing 2013 (Million)

Market Value of Equity (Market Capatalization) (digitallook.com) million

\section{Capital Structure}

Proportion of Debt

Proportion of Equity 


\section{Appendix v}

\begin{tabular}{|c|c|c|c|c|}
\hline Date & $\begin{array}{l}\text { FTSE } \\
\text { All } \\
\end{array}$ & $\begin{array}{l}\text { FTSE All } \\
\text { Return } \\
\end{array}$ & $\begin{array}{l}\text { WG.L } \\
\text { Equity }\end{array}$ & $\begin{array}{l}\text { W.G. L. } \\
\text { Return } \\
\end{array}$ \\
\hline $02 / 01 / 2015$ & 21.81 & 25213 & 55.04 & .04275 \\
\hline $01 / 1$ & .74 & 36 & & 08453 \\
\hline & & & & 065 \\
\hline & & & & \\
\hline & & & & \\
\hline $01 / 0$ & & & & 744 \\
\hline $01 / 07 / 2014$ & & 0405 & & .07005 \\
\hline $02 /($ & & .015 & & 4772 \\
\hline & & 0.009719 & & \\
\hline & & & & \\
\hline & & & & \\
\hline & & & & \\
\hline & & & & \\
\hline & & & & \\
\hline & & & & \\
\hline & & & & \\
\hline & & & & \\
\hline & & & & \\
\hline & & & & \\
\hline & & & & \\
\hline & & & & \\
\hline & & & & \\
\hline & & & & \\
\hline & & & & \\
\hline & & & & \\
\hline & & & & \\
\hline & & & & \\
\hline & & & & \\
\hline & & & & \\
\hline & & & 754 & \\
\hline & & & 2.69 & \\
\hline & & & & \\
\hline & & & & \\
\hline & & & & \\
\hline & & & & \\
\hline & & & & \\
\hline & & & & \\
\hline & & & & \\
\hline & & & & \\
\hline & & & & \\
\hline & & & & \\
\hline & & & & 394 \\
\hline & & & .34 & -0.197 \\
\hline & & & & \\
\hline & & & & \\
\hline & & & & \\
\hline & & & & \\
\hline & & & & \\
\hline & & & & -0.02146 \\
\hline & & 0.070324 & 8.32 & 0.197509 \\
\hline & & 2539 & 04 & 0.071868 \\
\hline $01 / 10 / 2010$ & 2936.15 & 0.023912 & 497.3 & -0.00253 \\
\hline
\end{tabular}




\begin{tabular}{|c|c|c|c|c|}
\hline $01 / 09 / 2010$ & 2867.58 & 0.063358 & 498.56 & 0.207138 \\
\hline $02 / 08 / 2010$ & 2696.72 & -0.00686 & 413.01 & 0.01594 \\
\hline $01 / 07 / 2010$ & 2715.36 & 0.067581 & 406.53 & 0.142067 \\
\hline $01 / 06 / 2010$ & 2543.47 & -0.04852 & 355.96 & -0.06198 \\
\hline $04 / 05 / 2010$ & 2673.17 & -0.06642 & 379.48 & -0.10097 \\
\hline $01 / 04 / 2010$ & 2863.35 & -0.0161 & 422.1 & 0.022009 \\
\hline $01 / 03 / 2010$ & 2910.19 & 0.063355 & 413.01 & 0.019325 \\
\hline $01 / 02 / 2010$ & 2736.8 & 0.028683 & 405.18 & 0.054827 \\
\hline $04 / 01 / 2010$ & 2660.49 & -0.03633 & 384.12 & 0.104269 \\
\hline $01 / 12 / 2009$ & 2760.8 & 0.042429 & 347.85 & 0.003259 \\
\hline $02 / 11 / 2009$ & 2648.43 & 0.0247 & 346.72 & -0.04142 \\
\hline $01 / 10 / 2009$ & 2584.59 & -0.01905 & 361.7 & 0.055904 \\
\hline $01 / 09 / 2009$ & 2634.79 & 0.045278 & 342.55 & 0.023546 \\
\hline $03 / 08 / 2009$ & 2520.66 & 0.07104 & 334.67 & 0.118363 \\
\hline $01 / 07 / 2009$ & 2353.47 & 0.08351 & 299.25 & 0 \\
\hline $01 / 06 / 2009$ & 2172.08 & -0.03576 & 299.25 & -0.05235 \\
\hline $01 / 05 / 2009$ & 2252.64 & 0.036621 & 315.78 & 0.177624 \\
\hline $01 / 04 / 2009$ & 2173.06 & 0.095198 & 268.15 & 0.080684 \\
\hline $02 / 03 / 2009$ & 1984.17 & 0.028201 & 248.13 & 0.157431 \\
\hline $02 / 02 / 2009$ & 1929.75 & -0.07175 & 214.38 & -0.00261 \\
\hline $02 / 01 / 2009$ & 2078.92 & -0.05901 & 214.94 & 0.031877 \\
\hline $01 / 12 / 2008$ & 2209.29 & 0.035286 & 208.3 & -0.11411 \\
\hline $03 / 11 / 2008$ & 2133.99 & -0.02276 & 235.13 & -0.11552 \\
\hline $01 / 10 / 2008$ & 2183.69 & -0.12078 & 265.84 & -0.29024 \\
\hline $01 / 09 / 2008$ & 2483.67 & -0.13421 & 374.55 & -0.28816 \\
\hline $01 / 08 / 2008$ & 2868.69 & 0.04346 & 526.17 & 0.127064 \\
\hline $01 / 07 / 2008$ & 2749.21 & -0.03729 & 466.85 & -0.14459 \\
\hline $02 / 06 / 2008$ & 2855.69 & -0.07351 & 545.76 & 0.108727 \\
\hline $01 / 05 / 2008$ & 3082.26 & -0.0057 & 492.24 & 0.038415 \\
\hline $01 / 04 / 2008$ & 3099.94 & 0.059066 & 474.03 & 0.05919 \\
\hline $03 / 03 / 2008$ & 2927.05 & -0.02853 & 447.54 & -0.01609 \\
\hline $01 / 02 / 2008$ & 3013.02 & 0.004307 & 454.86 & 0.092993 \\
\hline $02 / 01 / 2008$ & 3000.1 & -0.08719 & 416.16 & -0.1247 \\
\hline $03 / 12 / 2007$ & 3286.67 & 0.001768 & 475.45 & 0.054798 \\
\hline $01 / 11 / 2007$ & 3280.87 & -0.05016 & 450.75 & -0.01675 \\
\hline $01 / 10 / 2007$ & 3454.12 & 0.041373 & 458.43 & 0.05362 \\
\hline $03 / 09 / 2007$ & 3316.89 & 0.017301 & 435.1 & 0.098294 \\
\hline $01 / 08 / 2007$ & 3260.48 & -0.00871 & 396.16 & 0.110594 \\
\hline $02 / 07 / 2007$ & 3289.12 & -0.03379 & 356.71 & -0.03841 \\
\hline $01 / 06 / 2007$ & 3404.14 & -0.01005 & 370.96 & 0.090193 \\
\hline $01 / 05 / 2007$ & 3438.7 & 0.024765 & 340.27 & 0.107506 \\
\hline $02 / 04 / 2007$ & 3355.6 & 0.022049 & 307.24 & 0.04835 \\
\hline $01 / 03 / 2007$ & 3283.21 & 0.026555 & 293.07 & 0.005627 \\
\hline $01 / 02 / 2007$ & 3198.28 & -0.00422 & 291.43 & 0 \\
\hline $02 / 01 / 2007$ & 3211.84 & -0.00297 & 291.43 & 0.020056 \\
\hline $01 / 12 / 2006$ & 3221.42 & 0.032556 & 285.7 & 0.116059 \\
\hline $01 / 11 / 2006$ & 3119.85 & -0.00657 & 255.99 & -0.00211 \\
\hline $02 / 10 / 2006$ & 3140.47 & 0.029514 & 256.53 & 0.022806 \\
\hline $01 / 09 / 2006$ & 3050.44 & 0.014274 & 250.81 & 0.005976 \\
\hline $01 / 08 / 2006$ & 3007.51 & 0.001075 & 249.32 & -0.0076 \\
\hline $03 / 07 / 2006$ & 3004.28 & 0.012367 & 251.23 & -0.01281 \\
\hline $01 / 06 / 2006$ & 2967.58 & 0.017392 & 254.49 & 0.004302 \\
\hline $02 / 05 / 2006$ & 2916.85 & -0.0512 & 253.4 & -0.15825 \\
\hline $03 / 04 / 2006$ & 3074.26 & 0.008629 & 301.04 & 0.098806 \\
\hline
\end{tabular}




\begin{tabular}{|l|l|l|l|l|}
$01 / 03 / 2006$ & 3047.96 & 0.031068 & 273.97 & 0.065285 \\
\hline $01 / 02 / 2006$ & 2956.12 & 0.009411 & 257.18 & -0.02664 \\
\hline $31 / 01 / 2006$ & 2928.56 & & 264.22 & \\
\hline
\end{tabular}

